DOI https://doi.org/10.18551/rjoas.2021-03.16

\title{
ASSESSMENT OF PARTICIPATION LEVEL OF RURAL WOMEN IN FISH FARMING IN KADUNA STATE, NIGERIA
}

\author{
Olagunju Olubukola Eden, Ariyo Oluyinka Christopher* \\ Department of Entrepreneurship and Innovative Agriculture, Federal College of Forestry \\ Mechanization, Afaka, Kaduna \& Forestry Research Institute of Nigeria, Ibadan, Oyo State, \\ Nigeria

\section{Olagunju Olusegun Stephen} \\ Department of Agricultural Technology, Federal College of Forestry Mechanization, Afaka, \\ Kaduna \& Forestry Research Institute of Nigeria, Ibadan, Oyo State, Nigeria
}

Fadele Oluwaseyi Kayode

Department of Agricultural and Bio-environmental Engineering, Federal College of Forestry Mechanization, Afaka, Kaduna \& Forestry Research Institute of Nigeria, Ibadan, Oyo State, Nigeria

ORCID: 0000-0003-3880-8825

\author{
Alabi Olubukola Feyikemi, Ganiyu Lukman \\ Department of Agricultural Extension Management, Federal College of Forestry \\ Mechanization, Afaka, Kaduna \& Forestry Research Institute of Nigeria, Ibadan, Oyo State, \\ Nigeria
}

\section{Ademuwagun Adebola Abimbola}

Department of Basic Sciences and General Studies, Federal College of Forestry Mechanization, Afaka, Kaduna \& Forestry Research Institute of Nigeria, Ibadan, Oyo State, Nigeria

*E-mail: ask4ariyo@yahoo.com
ORCID:

\begin{abstract}
Attaining food security in Nigeria is a major concern with low level of food production. The study examined the level of participation of rural women in fish farming in Kaduna State. The objectives of the study were to describe socio-economic characteristics of fish farmers, determine the factors influencing the participation of respondents in fish farming identify the level of participation of rural women and describe the constraints to fish farming. Purposive sampling was used for the study. From the eleven (11) wards in Kagarko Local Government Area, six (6) wards were purposively selected, six (6) villages were randomly selected from each ward and twenty (20) rural women were randomly selected from each village to give a total one hundred and twenty (120) respondents. Data were collected using structured questionnaire. Descriptive statistics and Regression analysis were used to achieve the objectives while Chi-square was used to test the hypotheses. The mean age of the respondents was 39.2 years. Result revealed that membership in organization, inadequate capital, and source of labour were the factors influencing the level of participation. The major constraints facing the rural women in fish farming were lack of credit facilities and high cost of feeds. Chi-square revealed that membership in organization $(p=.017)$, years of experience $(p=.023)$, were significant to level of participation. The level of participation of rural women in fish farming is high (65.0\%). The study recommends that credit facilities at low interest rate should be given to rural women to promote their participation in fish farming and improve the standard of living of the rural family.
\end{abstract}

\section{KEY WORDS}

Participation, rural women, fish farming. 
Food security exists when all people, at all times, have physical, social and economic access to sufficient, safe and nutritious food to meet their dietary needs and food preferences for an active and healthy life (Idachaba, 2006). Nigeria is a country richly blessed with abundant natural and human resources that if properly harnessed can feed her people and export the surpluses to other countries to generate revenue (Huled, 2013). Yet, Nigeria is experiencing persistent food crisis both in terms of quantity and quality with cases of malnutrition and under nutrition growing by the day (Amao et al., 2006). One way to address malnutrition and poverty in developing regions involves fish farming as part of a diversified livelihood strategy (Gurun, 2012). Fish farming has great potential to enhance adequate nutrition and promote food security (World Bank, 2013).

Fish offer advantages as they may be more affordable, more available and consumed for preference in various regions of the world (Kawarazuka and Bene, 2011). Fish farming is an important venture in the quest for food security and eradication of malnutrition especially among households (Awotide, 2012). Fish farming is a sub-set of aquaculture that focuses on rearing of fish under controlled or semi controlled conditions for economic and social benefits (Anthonio and Akinwumi, 2002). Fish farming focused on private commercial fishing and the role played by fish farming to livelihood security of fish farmers, towards sustaining livelihoods in rural areas. Fish farming in Nigeria has the potential for satisfying the increased demand for protein and has been experiencing unprecedented growth during the last decade (Adeogun, 2012).

The rural economy in Nigeria is dominated by women through their participation in crop and animal production, marketing and processing (Adeyokunnu 2011). Rural women are mostly left behind when men migrate to urban areas in search for jobs and have given responsibilities to women to provide for their families through hard work, subsistence nature of agriculture with little income (Wetengere, 2009). Rural women adopt fish farming more due to the family economic demands. The participation of rural women in fish farming therefore extends to every aspect of fish farming like preparing fish feed, feeding the fish, cleaning of nets/cages and general maintenance and upkeep of the pond or cages (FAO, 2015).

Although rural women are often discriminated and mostly relegated to domestic chores. Women are accustomed to several daily routines such as cooking, child rearing, farming, livestock, poultry keeping and home gardening which have enabled them to accommodate fish farmingas well. Despite the challenges of rural women in Nigeria, they have shown great potential which have make them vital stakeholders in fish farming and survival of the rural communities. There is an existence of natural conditions for women to explore potentials needed in fish farming and a closer look into the challenges facing rural women such as gender inequality,inadequate land for farming, lack of capital and inaccessibility of good road network, which hitherto had posed a major threat to food production in Nigeria is needed.

Sessay and Odebiyi (2010) stated that Nigerian rural women play an important role in food production and nutrition of their families with the women providing up to $80 \%$ of the food crops, yet, they face much constraint as supported by the United Nations Development Programme (UNDP), (2013) that these rural women faced many constraints. Anyakoha and Mbanefoh (2010) found that these rural women who face enormous challenges and constraints in their role as providers of household nutrition security are under-rewarded resulting in poverty, environmental degradation, lack of appropriate technology, education and health. Many rural women farmers have poor health status, yet, the effective participation of women in fish farming help in sustaining development (UN, 2012).

The broad objective of this study is to assess the level of participation of rural women in fish farming in Kaduna state, Nigeria. The specific objectives designed for this study were:

- Describe socio-economic characteristics of fish farmers in Kagarko LGA of Kaduna State;

- Determine the factors that influence the participation of respondents in fish farming;

- Identify the level of participation of rural women in fish farming activities in Kagarko Local Government Area of Kaduna State;

- Describe the constraints to fish farming in Kagarko Local Government Area of Kaduna State. 
The hypotheses of the study were stated in the null form as follows:

- $\mathrm{H}_{0}$ 1: There is no significant relationship between the selected socio-economic characteristics and level of participation;

- $\mathrm{H}_{0} 2$ : There is no significant relationship between constraints and level of participation.

\section{METHODS OF RESEARCH}

The study was carried out in Kagarko Local Government Area (LGA) of Kaduna State. Kagarko LGA has an area of $1,864 \mathrm{~km}^{2}$ and a population of 240,943 at the 2006 census (National Population Commission, 2006). The people of Kagarko LGA are predominantly Koro and Gbagyi by tribe. It is an agrarian society. Crops such as ginger, turmeric, maize, beans, sorghum, millet, and rice are usually planted, while animals such as cattle, sheep, goat, fish and poultry are reared.

A multi-stage sampling technique was used for the study. In the first stage, six (6) districts were purposively selected from the eleven (11) districts because of the focus of the study (assessment of level of participation of rural women in fish farming). In the second stage, six (6) villages were randomly selected from each district and twenty (20) rural women were randomly selected from each village to give a total of one hundred and twenty (120) respondents.

Primary data were used which was obtained with the use of well structured questionnaire administered to each respondents by personal interview. The questionnaire was designed to capture the objectives of the study. The questionnaire was subjected to validity and reliability test. More information about the subject matter was obtained from the respondents by probing.

Descriptive statistics, multiple regression analysis, Chi-Square and Pearson Product Moment Correlation (PPMC) were used to achieve the objectives of the study. Descriptive statistics was used to analyze the socio economic characteristics of the respondents while multiple regression analysis was used to determine the factors influencing the level of participation of respondents in fish farming. Chi-Square and Pearson Product Moment Correlation (PPMC) were used to test the hypotheses.

\section{RESULTS AND DISCUSSION}

The socio-economic characteristics of the respondents were presented on Table 1. The mean age of the respondents is 39.2 years. This implied that the respondents were active and energetic to carry out the cultural practices involved in fish farming. This result confirms the report of Adekunle and Oke (2009) that rural women who are very strong can withstand pressure involved in fish farming towards meeting their household needs. From the table, majority $(81.7 \%)$ of the respondents were married. This implied that married women participate more in fish farming as a result of the required and needed help provided by the family members. In terms of income generation, majority $(76.3 \%)$ of the respondents were involved in other income generating activities such as trading, weaving, crop farming and tailoring, this is to augment their earnings especially during the off seasons. According to Attah (2012), rural women farmers who involved into agricultural production have other sources of income generating activities as an alternative to their other sources of income generating to the household. While most $(56.7 \%)$ of the respondents were members of cooperative society, some (10.8\% and $10 \%)$ were members of religious and work group respectively. This is essential as membership in one organization group or the other could give access to essential information and other necessary support such as loan and credit facilities or cooperative financing and marketing system.

Regression Analysis of Factors Influencing the Participation of Respondents in Fish Farming on Table 2 indicated that membership in organization $(\beta=.217, P=.004)$, Source of capital $(\beta=.235, \quad P=.002)$, Inadequate capital $(\beta=.158, \quad p=.018)$, Land clearing $(\beta=.245, P=.000)$, Lack of fish market, $(\beta=.158, P=.018)$, Pond construction $(\beta=.244, P=.000)$, Pond treatment $(\beta=.021, P=.004)$, Vaccination $(\beta=.332, p=.000)$, harvesting $(\beta=.199$, 
$P=.000$ ), types of fish (Tilapia $\beta=0.344, P=0.014$; Catfish $(\beta=.236, p=0.013$ ), Land acquisition $(\beta=.199, P=.004)$, Source of labour $(\beta=.187, P=.004)$ were significant to the participation of respondents in fish farming. Membership in organization helps the respondents with necessary needed finance and other inputs such as fertilizer, seed, and equipment involved in fish farming. Source of capital is one of the major channel to obtained money that is needed for fish farming, if the source of capital is not guaranteed, it could lead to shortage in fish farming while inadequate capital reduce farmers participation and income generation. Proper land for fish farming helps farmers with adequate space and also provide disease free environment for fish farming.

Table 1 - Distribution of Respondents Base on their Socio-Economic Characteristics

\begin{tabular}{|c|c|c|}
\hline Variables & Frequency $(n=120)$ & Percentage (\%) \\
\hline \multicolumn{3}{|l|}{ Age } \\
\hline $21-30$ & 13 & 10.8 \\
\hline $31-40$ & 56 & 46.7 \\
\hline $41-50$ & 45 & 37.5 \\
\hline 51 and above & 6 & 5.0 \\
\hline \multicolumn{3}{|l|}{ Marital status } \\
\hline Single & 3 & 2.5 \\
\hline Married & 98 & 81.7 \\
\hline Divorced & 5 & 4.2 \\
\hline Widowed & 14 & 11.7 \\
\hline \multicolumn{3}{|l|}{ Household size } \\
\hline $1-5$ & 39 & 32.5 \\
\hline $6-10$ & 54 & 45.0 \\
\hline $11-15$ & 14 & 11.7 \\
\hline 16 and above & 13 & 10.8 \\
\hline \multicolumn{3}{|l|}{ Educational status } \\
\hline Primary education & 20 & 16.7 \\
\hline Secondary education & 48 & 40.0 \\
\hline Tertiary education & 52 & 43.3 \\
\hline \multicolumn{3}{|c|}{$\begin{array}{l}\text { Other income generating } \\
\text { activities }\end{array}$} \\
\hline Trading & 76 & 76.3 \\
\hline Weaving & 13 & 10.8 \\
\hline Crop farming & 9 & 7.5 \\
\hline Tailoring & 22 & 18.3 \\
\hline \multicolumn{3}{|l|}{ Monthly income (N) } \\
\hline Below 10,000 & 3 & 2.5 \\
\hline $11,000-20,000$ & 12 & 10.0 \\
\hline $21,000-30,000$ & 22 & 18.3 \\
\hline $31,000-40,000$ & 30 & 25.0 \\
\hline $41,000500,000$ & 7 & 5.0 \\
\hline 51,000 and above & 46 & 38.3 \\
\hline Membership in & & \\
\hline \multicolumn{3}{|l|}{ Organization } \\
\hline Religious group & 13 & 10.8 \\
\hline Work group & 12 & 10.0 \\
\hline Farm club & 4 & 3.3 \\
\hline Cooperative society & 68 & 56.7 \\
\hline \multicolumn{3}{|l|}{ Sources of capital } \\
\hline Personal savings & 40 & 33.3 \\
\hline Family and friend & 8 & 6.7 \\
\hline Co-operative society & 63 & 52.5 \\
\hline Bank loan & 9 & 7.5 \\
\hline
\end{tabular}

Source: Field survey, 2019.

The market is place where buyers and sellers meet to do business lack of fish markets, could lead to low level of fish production which in turn affects the level of participation of rural women. Ponds construction lead to putting necessary structure in place for fish farming, 
having proper and adequate ponds for fish farming will increase their level of participation and boost fish production. Proper treatment of ponds provide conducive environment and disease free fish which helps in meeting market standards during harvesting and increased income thereby increase the level of participation of farmers in fish farming. Tilapia and Catfish are among the common and best types of fish sold by the rural women in the study area, these types of fish (Tilapia and Catfish) generate more income to the rural women when sold as a result of their demand. Land is one of the necessary elements considered in every type of business, land acquisition is therefore necessary and available to the respondents, and this makes them participate in fish farming due to availability of land. Availability of labour helps farmers to carryout agricultural production easily and save time for production, rural women participate more in fish farming when labour is cheap and available. This implied that rural women will participate more into fish farming when involved into organization, having capital, acquiring proper land, and available labour.

Table 2 - Regression Analysis of Determinants of Level of Women Participation in Fish Farming

\begin{tabular}{|c|c|c|c|c|c|}
\hline Variables & Std error & coefficient & T. & P-value & Remark \\
\hline Age group. & .082 & 0.40 & .312. & .756 & \\
\hline $\begin{array}{l}\text { Educational level } \\
\text { Other income }\end{array}$ & .032 & 0.25 & 496 & .621 & NS \\
\hline $\begin{array}{l}\text { Generating activities } \\
\text { Membership in }\end{array}$ & .023 & .101 & 1.788 & .078 & NS \\
\hline Organization & .021 & .217 & 2.998 & .004 & $\mathrm{~S}$ \\
\hline Lack of storage facilities & .074 & .032 & .550 & .584 & NS \\
\hline Source of capital & 0.34 & .235 & 3.256 & .002 & S \\
\hline Religion & .094 & .036 & .525 & .601 & NS \\
\hline Inadequate capital & .118 & .158 & 2.421 & .018 & S \\
\hline $\begin{array}{l}\text { Source of revenue } \\
\text { to government }\end{array}$ & .134 & .024 & .432 & .667 & NS \\
\hline Land clearing & .074 & .245 & 4.654 & .000 & $\mathrm{~S}$ \\
\hline Marital status & 0.38 & .122 & 2.239 & 0.28 & NS \\
\hline Lack of fish market & .080 & .158 & 2.421 & .018 & $\mathrm{~S}$ \\
\hline Inadequate women extension & .053 & .060 & 1.180 & .402 & NS \\
\hline Pond construction & .054 & .244 & 4.440 & .000 & S \\
\hline Dissemination against women & .065 & .027 & .501 & .618 & NS \\
\hline Pond treatment & .216 & .021 & .361 & .004 & S \\
\hline Filling of pond water & .216 & .021 & .361 & .719 & NS \\
\hline Vaccination & .073 & .322 & 4.975 & .000 & S \\
\hline Harvesting & .085 & 199 & 4.058 & .000 & S \\
\hline Pond fertilization & .121 & .096 & 1.743 & .086 & NS \\
\hline Tilapia & .246 & .344 & 2.530 & .014 & S \\
\hline Actual age & .009 & .019 & .148 & .883 & NS \\
\hline Cat fish & .603 & .236 & .297 & .013 & $\mathrm{~S}$ \\
\hline Years of experience & .029 & .003 & .048 & .962 & NS \\
\hline Land acquisition & .136 & .199 & 2.975 & .004 & S \\
\hline $\begin{array}{l}\text { Source of labour } \\
R=0.531\end{array}$ & .113 & .187 & 2.998 & .004 & $\mathrm{~S}$ \\
\hline
\end{tabular}

Distribution of Respondents based on their Level of participation in fish farming activities: The result on Table 3 revealed that larger percentage of the respondents participated in fish farming activities in the study area. All the respondents $(100 \%)$ participated in stocking of fish in the pond. Majority $(86.7 \%)$ of the respondents participate in land clearing operation during fish farming, while just few (13.3\%) of the respondents are not involved in the activity. (63.3\%) of the respondents in the study area are involved in the construction of pond to rear their fish. Majority of the respondents $(99.2 \%)$ are involved in treatment of their ponds to provide adequate and proper health for their fish. (98.3\%) of the respondents practice filling of ponds with water in other to provide a suitable water level for the fish while just few $(1.7 \%)$ of them do not practice that. Also $(95.0 \%)$ of the respondents are fully involved in pond fertilization, this is done so as to increase fish production which 
helps to stimulate the growth of microscopic plants, or algae, which feed the small animals that feed the fish, and only very few $(5.0 \%)$ do not practice pond fertilization.

The result further shows that $(100 \%)$ of the respondent fully participate in feeding their fish to increase their growth, and for them to reach early market weight, the result shows that $(83.3 \%)$ of the respondents participate in washing of the pond and just few $(16.7 \%)$ of the respondents do not participate in washing their ponds. Also $(76.7 \%)$ of the respondents involved in vaccination of their fish against disease that may affect the fish. $(91.7 \%)$ of the fish farmers involved fully in fish harvesting while just few $(8.3 \%)$ do not harvest their fishes. Harvesting is done mainly either for consumption or for sales.

Table 3 - Distribution of the Respondents base on their level of participation in fish farming

\begin{tabular}{llc}
\hline Activities & Yes & No \\
\hline Land clearing & $104(86.7)$ & $16(13.3)$ \\
Pond construction & $76(63.3)$ & $44(36.7)$ \\
Pond treatment & $119(99.2)$ & $1(.8)$ \\
Filling of pond with water & $118(98.3)$ & $2(1.7)$ \\
Stocking of fish in pond & $120(100.0)$ & \\
Pond fertilization & $114(95.0)$ & $6(5.0)$ \\
Feeding of fish & $120(100.0)$ & \\
Washing of pond & $100(83.3)$ & $20(16.7)$ \\
Vaccination of fish & $92(76.7)$ & $28(23.3)$ \\
Harvesting of fish & $110(91.7)$ & $10(8.3)$ \\
\hline
\end{tabular}

Source: Field survey, 2019. Figures in parenthesis are percentages.

Mean Score Distribution of Respondents on Level of Participation in Fish Farming activities on Table 4 showed high level of $65 \%$ and low level of participation of $35 \%$. The percentages of various activities involved in fish farming that cumulated to high level of participation includes feeding of fish $(100 \%)$, pond treatment $(99.2 \%)$, filling of pond with water $(98.3 \%)$, harvesting of fish $(91.7 \%)$, land clearing $(86.7 \%)$, and washing of pond $(83.3 \%)$. This revealed that the participation of women in fish farming activities cannot be over emphasized. Kelkar, (2001) stated that women are involved in various aquaculture activities, including purchase of fingerlings. Marketing is solely a women-dominated actively, while men are responsible for harvesting of fish. Feeding and maintenance of ponds are the activities carried out with the participation of both men and women (Kelkar, 2001). However, the position of women in meeting challenges of agricultural development cannot be ignored.

Table 4 - Mean Score Distribution of Respondents on Level of Participation in Fish Farming

\begin{tabular}{lll}
\hline Score & Frequency & Percentage (\%) \\
\hline High & 78 & 65.0 \\
Low & 42 & 35.0 \\
\hline Total & 120 & 100.00 \\
\hline
\end{tabular}

Source: Field survey, 2019.

Distribution of the Respondents Base on Constraints to Fish Farming on Table 5 showed the constraints index out of which high cost of feed accounted for $98.3 \%$, land acquisition $(94.2 \%)$, and source of labour (92.5\%). Lack of credit facilities $(84.2 \%)$, Poor breeds $(82.8 \%)$, inadequate source of water $(82.5 \%)$, inadequate fingerlings $(79.2 \%)$, and disease infestation $(75.8 \%)$ were the major constraints faced by rural women in fish farming in the study area. This implied that, the major constraints are: cost of feed, land acquisition and inadequate fingerlings, this showed that, the rural women found it difficult to obtained adequate feed required to feed their fish, this affect the quantity of fish produced by the rural women in the study area. This agreed with the findings of Roos et al, (2003) which stated that high cost of feed, land acquisition drastically decline the quantity and quality of fish produced in Nigeria, and these affect their level of income in fish farming activities. 
Table 5 - Distribution of the Respondents Base on Constraints

\begin{tabular}{lll}
\hline Constraints & \multicolumn{1}{c}{ Yes } & No \\
\hline Land acquisition & $113(94.2)$ & $7(5.8)$ \\
Source of labour & $111(92.5)$ & $9(7.5)$ \\
Disease infestation & $91(75.8)$ & $29(24.2)$ \\
High cost of feeds & $118(98.3)$ & $2(1.7)$ \\
Lack of credit facilities & $101(84.2)$ & $19(15.8)$ \\
Inadequate source of water & $99(82.5)$ & $17(17.5)$ \\
Poor breeds & $99(82.8)$ & $21(17.6)$ \\
Poor management practice & $88(73.3)$ & $32(26.7)$ \\
inadequate fingerlings & $95(79.2)$ & $25(20.8)$ \\
Size and type of pond & $87(72.5)$ & $33(27.5)$ \\
Inadequate power supply & $88(73.3)$ & $32(26.7)$ \\
\hline
\end{tabular}

Source: Field survey, 2019. Figures in parenthesis are percentages.

Correlation analysis between Social Economic Characteristics and Level of Participation: The correlation analysis between socio- economic characteristics and level of participation of respondent in fish farming on Table 5 showed significant relationship between religion $(r=.197, p=.031)$ and other income generating activities $(r=0.197, p=0.006)$. This implied that, religion and other income generating activities do not restrict rural women in fish farming activities. Thus, they participate more into fish farming activities. This implies that religion and other income generating activities play a key role in fish farming production in the study area.

Table 6 - Correlation between Socio-economic Characteristics and Level of Participation in Fish Farming

\begin{tabular}{lcll}
\hline Variables & r.value & p.value & Remark \\
\hline Age & .021 & .816 & NS \\
Marital status & .064 & .490 & NS \\
Religion & .197 & .031 & S \\
Purdah & .022 & .813 & NS \\
Other income & & & \\
Generating activities & .251 & .006 & $\mathrm{~S}$ \\
Monthly income & .007 & .096 & $\mathrm{NS}$ \\
\hline
\end{tabular}

Chi-square analysis between the socio-economic characteristics and level of participation in fish farming: Chi-square analysis on Table 6 revealed that membership of organization $\left(\chi^{2}=12.092 p=.017\right)$, years of experience $\left(\chi^{2}=9.568, p=.023\right)$, source of capital $\left(\chi^{2}=7.881, p=.049\right)$, were significant to level of participation in fish farming. Therefore the null hypothesis which states that there is no significant relationship between the selected socio-economic characteristics (membership in organization, years of experience, and source of capital) and level of participation of rural women in fish farming is hereby rejected. This implies that the respondents are members of organization which gives them access to finance, farms tools and necessary information to carryout fish farming. Source of capital also helps fish farmers to obtained founds and have access to loan which will lead to increase production of fish. The respondents also have adequate years of experiences which gave an insight on fish farming activities that is, the more the years they spent in farming the better the experience and the better their productivity.

Table 7 - Chi-square Analysis between the Socio-economic Characteristics and Level of Participation in Fish Farming

\begin{tabular}{lllcc}
\hline Variables & $\chi^{2}$ & Df & P-value & Remark \\
\hline Membership of organization & 12.092 & 4 & .017 & $\mathrm{~S}$ \\
Years of experience & 9.568 & 3 & .023 & $\mathrm{~S}$ \\
Source of capital & 7.881 & 3 & .049 & $\mathrm{~S}$ \\
Source of labour & .381 & 1 & .389 & $\mathrm{NS}$ \\
\hline
\end{tabular}


Chi-square Analysis on the Constraints to Level of participation in Fish Farming: The Chi-square result on Table 7 showed that Land acquisition $\left(\chi^{2}=4.336, p=.050\right)$ and lack of credit facilities $\left(\chi^{2}=5.943, p=.011\right)$ were significant to the level of participation. Therefore the null hypothesis which state that is no significant relationship between constraints; land acquisition, lack of credit facilities and level of participation in fish farming is here by rejected. This revealed that rural women in the study area find it difficult to have access to land and obtained credit for fish farming which has negative effect on their level of participation in fish farming. According to Kusakabe, (2003) the level of participation of rural women in fish farming decline over the years due to lack of access to credit and adequate capital to finance their fish farming.

Table 8 - Chi-square Analysis on the Constraints to level of participation in Fish Farming

\begin{tabular}{lllll}
\hline Variables & $\chi^{2}$ & $\mathrm{Df}$ & P-value & Remark \\
\hline Land acquisition & 4.336 & 1 & .050 & $\mathrm{~S}$ \\
High cost of feed & .201 & 1 & .579 & $\mathrm{NS}$ \\
Lack of credit facilities & 5.943 & 1 & .011 & $\mathrm{~S}$ \\
Inadequate source of water & 1.782 & 1 & .140 & $\mathrm{NS}$ \\
Poor breed & .462 & 1 & .340 & $\mathrm{NS}$ \\
Inadequate power supply & -.111 & 1 & .229 & $\mathrm{NS}$ \\
\hline
\end{tabular}

Source: Field survey, 2019.

\section{CONCLUSION}

It can be concluded from the result of findings that the participation of women in fish farming activities cannot be over emphasized; the level of participation of respondents in fish farming activities in the study area was high. Variables such as religions, other income generating activities, membership of organization, years of experience, source of capital, land acquisition and lack of credit facilities were significant to level of participation of respondents in fish farming.

It can be concluded further from regression analysis that membership in organization, source of capital, inadequate capital, land clearing, lack of fish market, pond construction, pond treatment, vaccination, harvesting, types of fish: catfish, land acquisition and source of labour were significant to the level of participation. The Cost of feed, land acquisition, source of labour, lack of credit facilities, poor breeds, inadequate water, inadequate fingerlings, and disease infestation were the major constraints faced by rural women in fish farming in the study area.

\section{RECOMMENDATIONS}

Based on the findings of the study, the following recommendations were made:

- Credit facilities at low interest rate should be provided by financial institution or government agencies to rural women, to promote their participation in fish farming, which will help them to have a better standard of living;

- Rural women should be given access to land to encourage them to participate more in fish farming which in turn will improve the nutritional status of rural households and improve economic well-being;

- Rural women should be encouraged to belong to one organization group or the other to give them access to necessary information, inputs and benefits that will promote their fish farming activities.

\section{REFERENCES}

1. Adeogun, O. A. (2012). Status, cost and profitability of aquaculture enterprises in Nigeria: implications for food security. International Journal of Agricultural Sciences, 2(1): $059-066$. 
2. Adekunle, $\mathrm{K}$ and Oke, F. (2009). Gender participation in Urbanfishery marketing and Production in Ghana: Characteristics and Risks. Accra, Ghana. 3(2) 34-50.

3. Adeyokunnu, O. O (2011). Determinants of Extension Service Needs of Catfish farmers in Oyo State, Nigeria (A case study of Ido Local Government Area)". Journal of Humanities and Science 1(4): 54-58.

4. Amao J. O., Oluwatayo I. B. and Osuntope F. K. (2006). Economics of fish demands in Lagos State, Nigeria. Journal of Human Resources and Ecology. 19(1):25-30.

5. Anthonio, O. R and Akinwumi J. A. (2002). Supply and distribution of fish in Nigeria. Geographical Journal. 14: 16-16.

6. Anyakoha, S and Mbanefor, S. (2010). Common Moorhen Gallinulachloropusin the diet of the African catfish Clariasgariepinusin Keoladeo Ghana National Park, India. Indian Birds 2000; 5(Pt 2): 22-3.

7. Attah. E., (2012) "Food Security in Nigeria: The Role of Peasant Farmers in Nigeria". African Research Review. An International Multidisciplinary Journal, Ethiopia 6(4): 173-190.

8. Awotide, B.A. (2012) Poverty and Inequality among Fish Farming Households in Oyo State, Nigeria. Agricultural Journal, 7(2): 111 - 121.

9. FAO (2015). Fisheries development in Nigeria; the current challenges. Paper presented by the honorable of state for agriculture to the fisheries society of Nigeria (FISON) Lagos state 23pp.

10. Gurun, D. (2012). Fish processing: Food Cycle Technology Source books, International Technology Publications, London, $66 \mathrm{pp}$.

11. Huled, F. (2013). Market Access for Small-Scale Farmers in South Africa. In: L. Nieuwoudt and J. Groenewald (eds.). The Challenge of Change. Pietermaritzburg, University of Natal Press. 4(3) 56-71.

12. Idachaba F. S. (2006). Strategic and policies for food security and economic development in Nigeria. Lagos: Journal of Agriculture 3(9), 3-9

13. Kawarazuka, $\mathrm{N}$ and Bene, $\mathrm{C}$. (2011). The potential role of small fish species in improving micronutrient deficiencies in developing countries: Building experience. 2(14) 1927-1938.

14. Kelkar, G. (2001). Gender concerns in aquaculture: women's roles and capabilities. In: Kusakabe K. and Kelkar, G. (Eds.), Gender Concerns in Aquaculture in Southeast Asia .Asian Institute of Technology, Thailand, 1-10.

15. Kusakabe, K. (2003). Women's Involvement in Small-scale Aquaculture in Northeast Thailand. Development in Practice, 13 (4): 333-345.

16. National Population Commission (NPC). (2006). National Population Commission, 2006 Population Census Figure.

17. Roos, N, Islam, M. And Thilsted, S.H. (2003). Small indigenous fish species in aquaculture in Bangladesh: contribution to vitamin A, calcium and iron intakes. Journal of Nutrition 133:4021S-6S.

18. Sessay, A and Odebiyi, R. (2010). The Nigerian Fisheries and the Attainment of the Millennium Development goal. Fishnetwork.Vol.4No 3 Oct-Dec 2010. Characteristics influencing adoption behavior of women co-operative and non -cooperative in Oju Local Government area of Benue State. Journal of Agricultural Extension 2(4) 31 -38.

19. United Nation (UN, 2012). Commission on the Status of women CSW56.http://www.un.org/womenwatch/daw/csw/csw56/documentation.html.

20. United Nation Development Programme (2013) Construction of Levee Ponds for Commercial Catfish Production. U.S Department of Agriculture, Washington, D.C.

21. Wetengere. B. (2011). Fish cage culture potential in Nigeria an overview. National Cultures Agriculture Focus; 5:10.

22. World Bank. (2013). Aquaculture: Changing the Face of the Waters. Meeting the Promise and Challenge of Sustainable Aquaculture. The World Bank, Washington DC. 